\title{
Cultivated Circles of The Empire: Bibliographical Notes on W.S. Jevons's Antipodean Interlude (1854 -1859) ${ }^{1}$
}

\author{
Michael V. White*
}

\begin{abstract}
Describes the various components of W.S. Jevons's work in Australia between 1854 and 1859 and the context in which it was produced. Explains how a complete list of Jevons's Antipodean publications has been compiled from his sometimes confusing records. Discusses his social survey of Sydney, demonstrating that his manuscript was censored when published in 1929 by the Sydney Morning Herald. An appendix lists all Jevons's Australian publications.
\end{abstract}

I am becoming quite accustomed to the pen as a weapon of offence and defence....I often write a newspaper article and am then on thorns for ever so long after for fear of a libel action.

William Stanley Jevons, October 1858

\section{Introduction}

In August 1882 the weekly Sydney Mail published an obituary, accompanied by an etching, of William Stanley Jevons that recalled his time in Australia between 1854 and 1859 when he was an assayer at the Sydney branch of the Royal Mint (Figure 1). It was noted that Jevons 'is well remembered by many citizens of Sydney' because he 'gave proof of the mental power and industry which has since made him famous throughout the cultivated circles of the empire'. The proof was Jevons's work on the climate of Australia, compiling meteorological records after their collection was suspended by the government in 1855, presenting a 'valuable' series of papers to the Philosophical Society of New South Wales and producing a monograph-length analysis of the Australian climate with a paper on geology. ${ }^{2}$ By the sesquicentenary of his arrival in Australia, it was evident that Jevons's work had been far more extensive than indicated by the Mail. The Appendix to this paper shows that 39 published items can be attributed to his Antipodean interlude. As noted by the curators of the sesquicentenary Powerhouse Museum exhibition, 'William Stanley Jevons in Sydney: The Curious Economist', the assayer is now also remembered for work that included experiments on cloud formation, photography, a social survey of Sydney and topics in political economy (Barrett and Connell 2004). ${ }^{3}$ Moreover, as will be indicated below, it is now possible to identify two unpublished manuscripts - one on music and the other on the division of labour - that further illustrate the extent and quality of his work at the time. This record is particularly remarkable as Jevons was only nineteen when he first arrived in Sydney. 
Figure 1: A Jevons Obituary 
Historians of economics may not be completely familiar with the extent of Jevons's Antipodean work and the associated secondary literature which has been published in different disciplines. In providing an introduction to those topics, these notes are presented in four main sections. The first discusses the various components of Jevons's work and sketches the context in which it was produced. The following two sections explain how the publications were identified from Jevons's sometimes confusing records. The fourth section provides a local context for Jevons's social survey of Sydney and shows that his manuscript was censored when much of it was published by the Sydney Morning Herald in 1929.

\section{$1 \quad$ Jevonian Networks}

Jevons's list of publications is dominated by items on meteorology and geology, the analysis of which was underpinned by his training in chemistry that was crucial for his role as an assayer. If that work was praised by Sydney contemporaries, subsequent commentary has examined the innovations in his detailed analysis of climate and the experiments in simulating cloud formations. ${ }^{4}$ A number of the papers were published in scientific journals in Australia (papers and records of proceedings at the Philosophical Society appeared in the Sydney Magazine of Science and Art (Dyer 1858-59)) and Britain (the London, Edinburgh, and Dublin Philosophical Magazine and Journal of Science). In terms of the number of publications, however, a principal outlet for Jevons's work was the Empire, a Sydney newspaper edited by Henry Parkes. In the absence or failure of scientific journals in Australia (the Sydney Magazine folded after two volumes), the local press played a key role in reporting, reprinting and enabling debate on scientific issues. ${ }^{5}$

Jevons also used the Empire and, after the bankruptcy of that newspaper in 1858, the Sydney Morning Herald to publish a second group of items in the publications list. These both reflected and contributed to his new-found interest in the social sciences. Much of that work was directed toward contemporary debates in the colony regarding government policy such as tariffs, the sale of land, immigration, the construction of railways and sanitary conditions, including the Sydney water supply. Jevons also undertook a large project, beginning in late 1856, which he entitled 'Notes and Researches on Social Statistics or the Science of Towns especially as regards London and Sydney'. ${ }^{6}$ Unpublished at the time, the project had two components. The first was a topographical survey of Sydney, mapping different districts of the city in terms of the type of houses, the occupations and social rank of the inhabitants, the location of industries and sanitary conditions. Now known as the 'Social Survey', it remained in manuscript until 1929 when much of it was published by the Sydney Morning Herald in six parts (beginning 9/11/1929, ending 7/12/1929) with an introduction by Winefrid Jevons (6/11/1929), who had found the manuscript among her father's papers. ${ }^{7}$ The second component, which provided the occupational categories for the first, was a detailed statistical investigation of trades and professions in London. The point of the calculations was to 'obtain proportional statistics' for each trade and profession. ${ }^{8}$ The experience gained in dealing with the complexity of the statistics in that regard was crucial for Jevons's next project, specifically concerned with the (social) division of labour, which he began in June 1857. Summarised in a large chart, which reflected his work in geology, the division of labour project distributed the population between different occupational groups in the economy. Based in part on detailed statistics from the British census, it was the first of Jevons's statistical charts in political economy. ${ }^{9}$ 
Although Jevons has been depicted as an isolated and solitary figure in Australia (Walsh and Gram 1980, pp. 126-7), this is a caricature. While he was not part of the colonial social elite, ${ }^{10}$ Jevons maintained friendly and productive contacts with Professor John Smith from the University of Sydney (see below) and the Rev. William Branwhite Clarke, geologist, astronomer and meteorologist (Organ 1992; Moyal 2003). ${ }^{11}$ Another Jevons network is illustrated by the record of his photography, where the cumbersome equipment of the time and difficulties with atmospheric conditions required collaboration between a group of photographers. Historians now place Jevons in a group within the Philosophical Society that included members from the Mint, especially Robert Hunt, the first clerk of the bullion room, and Professor Smith. One result of the collaboration is that it is sometimes difficult to attribute a photograph to a particular person within the group. $^{12}$ An example is a photo, initially attributed to Jevons, of debris from the passenger ship Dunbar that was wrecked near the entrance to Sydney Harbour in 1857 (Burke 1955, pp. 16-17). The picture was taken by Hunt, whose two sisters died in the wreck (Newton 1988, p. 178). ${ }^{13}$

Further resources for exploring the context of Jevons's Antipodean interlude have been provided by the Historic Houses Trust of New South Wales. Following a major conservation project, the Trust's head office is now located in the building, originally constructed in 1854-1855, that housed the Mint's coining factory and accommodation for office staff. The Trust's Library and Research Collection has produced a number of studies discussing the significance of the Mint and its employees, including Jevons. ${ }^{14}$ Those studies make it clear that the Mint was important for Jevons's work because of the talented staff and the 'spirit of experimentation and enquiry cultivated within the....establishment'. Indeed, during the 1850s and 1860s, the Mint helped strengthen 'colonial science through its greater institutionalisation' (Martin 2003a, p. 4). That context provides glimpses of the technical collaboration required for a number of Jevons's projects. The first illustrations for his sun-gauge paper (item 14) were drawn by Henry Severn, then clerk and another photographer at the Mint, who was subsequently to make an eleven-inch Newtonian reflector in the late 1850s. Technical expertise was also required for the construction of equipment. Referring to the sun-gauge in 1857, Jevons complained of 'the want of an instrument maker to blow the glass and make the vacuum' and, in late 1858, 'I must put the matter in the hands of Flavelles the instrument sellers, who say they can make it'. While Jevons apparently made the equipment for his cloud simulation experiments (items 21, 23), he may have drawn on the skills of Mint colleagues and his assistant Charles Bolton who had accompanied him from Liverpool. An undated letter from Bolton to Jevons has a neat illustration, tinted with washes, of a chemistry bench and apparatus (Figure 2). Bolton also reported modifications to a Bunsen burner, again illustrated with a diagram, which he offered to make for Jevons (Figure 3). ${ }^{15}$

The publication list here also undermines the depiction of Jevons as an isolated figure, as it shows he was an active participant in debates on contemporary issues, including capital punishment (item 26). As a government employee, many of his publications were signed with pseudonyms. With that protection, Jevons was able to give full vent to attacking a number of local officials and the government. Marked by both careful analysis and polemic, the publications also reveal much about Jevons's general philosophy and particular approach to economic, social and political issues. 
Figure 2

Page from undated letter by Charles Bolton to W.S. Jevons

[JA6/3/2] 
Figure 3

Page from undated letter by Charles Bolton to W.S. Jevons

[JA6/3/2] 
As was indicated above, it is well known that Jevons turned his attention to the social sciences, particularly political economy, while in Australia. Recent work has begun to explore the precise ways in which Jevons utilised his training in the physical sciences to construct the theoretical and statistical components of his economics. In this regard, Jevons's Antipodean interlude has taken on a new significance (Maas 2005; White 2004 and 2006). Attention has also been drawn to Jevons's unpublished manuscript on music written in Australia that discussed both the physics of music and its relation to Jevons's utilitarian philosophy (JA 6/47/117; Kassler 1996; Mosselmans and Mathijs 1999). One prerequisite for analysing the significance of the Antipodean interlude is a full list of Jevons's publications. The difficulty here has been that his records were incomplete and misleading. When the final volume of the Jevons Papers and Correspondence was published in 1981 (Black and Könekamp 1972; Black 1973-81), thirty items in the list had been identified. Inoue and White (1993 and 2001) added nine items, but gave no explanation for the attributions. For the record, an explanation is given in section 2. The following section is concerned with the identification of one item that requires a more detailed discussion, thereby providing further context for Jevons's time in Australia.

\section{Identifying Jevons's Publications}

The list of Jevons's Australian publications draws on four sources. The first, Jevons's Letters and Journal, edited by his wife and published in 1886, listed thirteen items (Jevons 1886, pp. 459-60). John La Nauze's pioneering study, Political Economy in Australia, subsequently identified a further fourteen publications (La Nauze 1949, pp. 39-44). ${ }^{16}$ The third source is the Papers and Correspondence which, in reprinting a number of Jevons's publications and his Australian journal, added three further items. ${ }^{17}$

Volume 7 of the Papers and Correspondence also reprinted a list of 'Additional Writings' from one of Jevons's notebooks. ${ }^{18}$ That list, which is incomplete, records 21 publications during Jevons's time in Australia. Ten of the entries were known when the Papers and Correspondence was published (items 1, 7, $14,15,20,25,29,30,35,36)$. The bibliography by Inoue and White (1993 and 2001) then identified nine further items $(10,16,18,19,24,26,27,28,38) .{ }^{19}$ This was not straightforward, as the notebook records incorrect dates for most of the entries. It was also concluded from that research that three of the notebook entries were not published. The following is a summary of how those conclusions were reached.

Six publications, listed in the notebook as published in the Empire, can be identified, as their titles correspond to publications in that newspaper (items 10, 16, 19, 24, 26, 27). However, only two were given the correct publication date; the others were published in a different month or year. A possible explanation for the confusion is that, when he began the notebook list in February 1862, Jevons was working from rough notes and an incomplete memory. This may explain why, of the remaining five items to be accounted for in the notebook, three do not seem to have been published.

Jevons listed 'Red Tapeism \& the Newcastle Lifeboat' in the notebook as written for the Empire on November 20, 1856. His diary, however, recorded that it was written and delivered to the Sydney Morning Herald on that date (JA 6/4/2). I was unable to find such a letter in either newspaper and suspect that it was sent to the Herald but never published. That could help to explain why Jevons subsequently used the Empire as an outlet, particularly as he was by then writing the paper's meteorological reports. 
The notebook also records a publication in the Empire for September 1857, entitled 'On the Philosophical Society of N.S.W.' This appears to have been conflated with a review of the Sydney Magazine of Science and Art, published by the Sydney Morning Herald in the same month (item 28), which is also recorded in the notebook list. If the item had been published in the Empire, it must have appeared between August 3 (item 28) and the end of August when, as Jevons put it, the Empire 'passed away in bankruptcy' (Black 1973-81, 2, p. 346). I was unable, however, to find such an article in the Empire or the Herald before September 1857. Because of the similarity in topics, I suspect that Jevons confused two separate items when writing the notebook list after he had returned to England. A possible explanation is that he originally wrote the review for the Empire and, with the demise of that paper, sent it to the Herald. He may, however, have recorded the two entries in notes.

A further conflation seems to have occurred between Jevons's notebook entry for a 2 October 1856 publication, written for the Empire, on 'Lead Poison in the Sydney Water, Vindicating Dr. Smith', and an entry for the Empire listed for September 1857, recorded only as 'Letter on a local subject'. I concluded that there was only one letter, 'Lead Poison in the Sydney Water', written on 2 October 1857 and published by the Empire on 5 October (item 18). The reasons for that conclusion require a more detailed explanation.

\section{The Lead Poison Letter}

When the University of Sydney was founded in 1852, there were three foundation professors: Morris Pell (mathematics and natural philosophy); John Woolley (classics); and John Smith (chemistry and experimental philosophy). Jevons may have known Pell, as the three professors were members of the Philosophical Society. Jevons certainly supported Pell's critique of the government policy of expanding railway lines in debates at the Society, using one of Pell's papers in his own analyses that were published by the Empire and the Sydney Morning Herald (items 1, 3, 8, 20). Jevons also drew on a paper by Woolley when formulating remarks on a utilitarian theory of behaviour recorded in his Australian journal. ${ }^{20}$

The original prospectus for the University had included a chair in natural history for which an enthusiastic Thomas Huxley intended to apply. He did not do so, however, because, in 1850, the chair designation was changed to one for chemistry, to which Smith was elected. Whatever the effects of the change for the University, ${ }^{21}$ it was important for Jevons, as he and Smith were on friendly terms. ${ }^{22}$ Before Jevons left for Australia in 1854, his cousin, the chemist Henry Roscoe, urged him to obtain a letter of introduction to Smith from Thomas Graham, professor of chemistry at University College London and Master of the London Mint from 1854, who had recommended Jevons for the assayership at the Sydney Mint. Graham's correspondence with Smith could explain Jevons's reference to a visit from Smith in mid-1855. The two were in contact after this, ${ }^{23}$ and Smith read Jevons's papers to the Philosophical Society (items 14, 21) as Jevons was uncomfortable in publicly presenting his work. On his return to England Jevons maintained contact with Smith, meeting him at the British Association for the Advancement of Science at Manchester in 1861. Smith also recommended Jevons to Graham for a lectureship at Anderson's Institute at Glasgow in 1862. The friendship with Smith helps explain the identification of Jevons as the author of a letter on pollution of the Sydney water supply that was published by the Empire in October 1857. 
In early 1851, the Sydney Morning Herald published a series of ten articles on the deplorable state of sanitary conditions in Sydney. Driven by the fear of disease spreading from the poorer to the wealthier sections of the city, potential political unrest and a power struggle between the Legislative Council and the Sydney City Council, ${ }^{24}$ the articles focussed on 'ramshackle dwellings, inadequate drainage and sewage facilities, and a totally inadequate water supply'. The latter was deficient in both quantity and quality. With only thirteen per cent of Sydney houses connected to a mains water supply, householders had to rely on expensive water carriers. Wells were also a problem, as they were dug near latrines. Further pressure came from manufacturers who were heavy users of water, especially with the increasing use of steam engines. Reflecting the contemporary debate, Jevons's social survey of Sydney criticised the deplorable state of dwellings and the water supply (Clark 1978, pp. 56-7).

Amidst charges of ineptitude and corruption, the City Council was replaced by three commissioners in 1853. Smith then prepared a report for the commissioners on pollution of the water supply, drawing particular attention to poisoning due to the use of lead in pipes and cisterns. ${ }^{25}$ In the main, Smith’s campaign against the use of lead 'went largely unheeded' (Clark 1978, p. 60; Sheldon 1988, p. 75), with criticism from Dr Isaac Aaron who was appointed Officer of Health for the reconstituted Council when the commissioners were replaced in $1857 .^{26}$

On 13 August 1856 Smith read a paper entitled 'On the Action of Sydney Water Upon Lead' to the Philosophical Society. ${ }^{27}$ Jevons was deeply impressed, describing the paper as 'excellent'. Over the next two days, he confirmed Smith's results by his own experiments on water at the Mint, noting in his diary that the lead could be removed 'entirely' by means of a sand or stone filter. ${ }^{28}$ In October, he reported to his cousin, the chemist Henry Roscoe, that Smith had 'discovered that all Sydney was being poisoned by lead pipes (myself a most serious case, too), but that all lead whether in solution or not could be removed perfectly by sand filtration similarly to what I have since observed in the Phil. Mag about sand-filtration in London. (Paper by Witt of the Gov. School Chem.). ${ }^{29}$

As was noted in section 2, Jevons's notebook records a publication in the Empire, which was written on 2 October 1856, 'Lead Poison in the Sydney Water, Vindicating Dr. Smith'. I was unable to find such a letter in the Empire for October. Indeed, the discussion in that newspaper of Smith's analysis had ceased before that month. The matter was, however, raised again in late September 1857, following the publication of the first quarterly report by Aaron. ${ }^{30}$ After an editorial in the Empire suggested that the report had impugned Smith's work, a long letter was published in the Empire on 5 October, with the heading of 'Lead Poisoning in the Sydney Water'. Written on 2 October, the letter was an explicit vindication of Smith, defending the originality and superiority of his paper as compared with Witt's, and reporting the results of an experimental test for lead-poisoning and an improved water filter based on that suggested by Smith.

With Jevons's work in chemistry (cf. the complex experiments described in items 21 and 23), ${ }^{31}$ the extraordinary coincidence of subject matter and the 2 October dates of the 1857 Empire letter and Jevons 1856 notebook entry, it can be concluded that the 1857 letter was written by Jevons which thus appears as item 18 in the publications list. Jevons's notebook record of an 1857 'letter on a local subject' to the Empire which was published between 19 September (item 17) and 14 November (item 19) appears, therefore, to have been the result of his confusing 1856 with 1857 when dating the lead poison letter in the notebook after he had returned to England. 


\section{$4 \quad$ The Social Survey}

In his insightful account of Jevons's social survey, Graeme Davison rightly argued that it should be placed in the context of the nineteenth-century British social and statistical inquiries into the urban poor by middle-class reformers (Davison 1997/98). It needs to be noted, however, that Jevons's project should also be considered in the context of the extensive debates over sanitary reform and the need for the collection of economic and social statistics in Sydney. That context can help explain a number of Jevons's remarks regarding public officials.

In September 1856 Isaac Aaron presented a paper on 'sanitary reform' to the Philosophical Society. Detailing his own experiences of the shocking conditions in 'which many of the poorer classes in this city exist', Aaron criticised landlords for the deplorable state of dwellings and called for an extensive reform programme including the regulation of boarding houses and of the pollution emitted by steam engines and foundries, the macadamisation and sluicing of roads as well as the provision of public baths and wash-houses (Aaron 1858, pp. 196-8). In December, the Registrar General, Christopher Rolleston, presented a paper to the Society on 'The Science of Statistics'. Surveying the history of public statistical collections in Europe and particularly Britain, where he referred to the London Statistical Society and the importance of L.A.J. Quetelet, Rolleston noted that 'writers on science and political economy' expressed regret at the lack of statistics which 'could trace the progress of a country' ${ }^{32}$ He concluded that 'it will be no unworthy object of this society to take a part in furthering investigations which help to solve problems of deep social and economic importance' (Rolleston 1857a, pp. 257-8). Following the paper it was moved that 'a committee be appointed to collect, as far as practicable, information as to the social economics and statistics of Sydney'. The committee members included Rolleston and Aaron (Maiden 1918, p. 269). In presenting a subsequent paper on sanitary reform the following June, however, Rolleston acknowledged that the committee had done no work, in part because the appointment of Aaron as City Health Officer would result in statistical collections being 'carried out with greater precision' (Rolleston 1857b, p. 37). As RegistrarGeneral, Rolleston did, however, publish mortality and nosological tables, dealing with the causes of disease, in the Sydney Magazine (Coward 1988, p. 58).

Although Jevons had begun work on his science of towns project in November 1856, he was not made a member of the committee, possibly due to his own diffidence but more likely because he was regarded as a junior member of the Society. ${ }^{33}$ This may be relevant in considering Jevons's criticism of Rolleston and Aaron in his article, 'The Social Cesspools of Sydney. No. I - The Rocks', which drew on the description of the Rocks in his social survey ${ }^{34}$ and was published by the Sydney Morning Herald in October 1858 (item 29). Jevons noted that while Rolleston had 'enlightened' the public regarding the Sydney mortality rate, 'I cannot participate in the alarm employed by that functionary'. He also made scathing remarks on Aaron's failure to discuss the Rocks in his first report as City Health Officer. Those remarks should be read in the context of Jevons's 1857 letter, discussed above, on lead poisoning of the Sydney water supply, where he attacked Aaron for slighting the work of Professor Smith in his report.

When the Sydney Morning Herald printed much of the social survey in 1929, a series of deletions were made from the manuscript. A number of these were for editorial reasons, such as the omission of the description of the missing map and some topographical descriptions of the Rocks, Camperdown and Pyrmont. 
However, as Groom and Wickman noted when they reprinted extracts from the original copy, the manuscript was also 'subjected to the censorship of the day' (Groom and Wickman 1982, p. 3). ${ }^{35}$ Although they did not specify what was censored, three items can be identified. First, in the discussion of the Rocks, the Herald (13/11/1929) deleted Jevons's passage discussing an 'intoxicated' young woman with a 'wicked dissipated face' and an older woman who illustrated 'probably a later stage of a life of wickedness'. (That passage also appeared in the 1858 Herald article on the Rocks.) Second, the following sentence concludes Jevons's manuscript discussion of Wolloomooloo: 'Brothels are said to exist in the flat parts of Wooll ${ }^{\circ}$ and some houses of the first class bear no good name, but it is uncertain how far such statements can be received'. This unfortunate reflection on some of the first-class houses was omitted from the Herald version (16/11/1929). Third, in Jevons's discussion of Durand's Alley, the original read: 'some female inhabitants....are punished almost every day at the Police Court for offenses chiefly connected with prostitution'. The Herald version changed 'prostitution' to 'the streets' (23/11/1929).

Who censored the manuscript? It might have been Winefrid Jevons, although that seems unlikely as one part of the survey escaped the censor's pen. In Jevons's discussion of West Sydney, the following appeared in the Herald (13/11/1929): 'there is a remarkable number of lodging or boarding houses, which generally consist of small dirty cottages, and are really brothels or little better. During the day, women of repulsive appearance and the worst character may be seen hanging about the doors, awaiting the night's debauch'. This uncensored piece appeared before the censored ones, which suggests that the manuscript was censored at the Herald. Perhaps the initial lapse in taste was not noticed, or there may have been a complaint. (In noting that only one instalment of Jevons's projected series on the 'social cess-pools of Sydney' was published by the Herald in 1858, La Nauze (1943, p. 267) speculated that this might have been due to 'complaints'.) ${ }^{36}$

Despite Jevons's interest in personally verifying the existence of the demimonde, there are some grounds to suspect that he was not completely au fait with that subject. The following extract is from his diary, regarding a trip to the Sofala diggings in March 1856:

We dined at the Wyagden Inn, an extraordinary wooden construction of considerable size, inhabited almost entirely by a number of females, in a way not easy to understand the reason of.

Here we were told that the nearest diggings were four miles off....

(Black and Könekamp 1972, p. 227).

\section{Conclusions}

Some odd claims have sometimes been made about Jevons's time in Australia. For example, according to one newspaper columnist:

Jevons acquired some knowledge of the regular sunspot cycle in his years at the Sydney Observatory and later noticed that this seemed connected with cycles in plant growth (as, for example, displayed by the rings of tree-trunks). From this he developed a fascinating theory explaining the business cycle in terms of sunspots and their influence on harvests. Unfortunately it does not work. (McGuinness 1988) 
The same journalist has since been appointed by the Australian government to a committee that vets academic research funding proposals. He was reported as defending his suitability for that role by declaring that 'I am.... a person who's read extremely widely and deeply in the social sciences all my life. I'm well qualified in economics and related subjects'. ${ }^{37}$ Indeed, it is fortunate that he is vetting research applications since, as he has also observed, 'Scholarship is a rare thing in our universities these days, and rarer still in the social sciences, like economics' (McGuinness 2003, p. 117). In the light of that statement and his autoqualifications, it is distressing to have to record that, with the exception of the last sentence, his claims about Jevons cited above are nonsense. ${ }^{38}$ Indeed, there is some poignancy here in that, because the claims were first made in 1988, they are, perhaps, some of the earliest examples of the Postmodernist virus which, as the same journalist has often reminded us, is now dominant in academia. ${ }^{39}$

There is, however, no need to resort to fiction in considering the significance of Jevons's Antipodean interlude. In a letter written in February 1858, he made clear the turn to the social sciences in Australia that was subsequently to dominate his work:

knowledge of man and society is perhaps the most useful and necessary work in which any one can now engage. There are plenty of people engaged with physical science, and practical science and arts may be left to look themselves, but to thoroughly understand the principles of society appears to me now the most cogent business (Black 1973-81, 2, p. 322)

In 1998, a report for the Australian Research Council on Challenges for the Social Sciences and Australia used that quotation as an introduction with a montage on its cover dominated by a Jevons photographic self-portrait. ${ }^{40}$ The use of the figure of Jevons in that way was apt in that his work in Australia has been cited and analysed by economists, geographers, meteorologists, oceanographers and historians. ${ }^{41}$ More popular histories or anthologies of Sydney have also referred to or cited his social survey (Birmingham 1999, pp. 204-5; Flannery 2003, pp. 288-91). Indeed, it has been argued that Jevons's description of the Rocks has become 'so well-known as to be unquestioned', creating a stereotype of that area as 'a place of filth, vice and misery' (Karskens 2001, pp. 69-70).

Although Jevons adopted what today might appear to be a stereotypical mid-nineteenth-century liberal position on many policy issues in Australia, examination of his published work also reveals some surprising exceptions. For example, while he was, and continued to be, a dogmatic proponent of 'free trade' for most commodities, he argued in 1858 that scientific publications in the colony required protective measures (item 28). It should also be noted that, following his return to England, Jevons wrote in 1876 that 'accounts which I have heard of the proceedings in the border districts of Queensland are simply dreadful....English society....has never cared even to ascertain whether of not scores of the Australian natives are shot like kangaroos or poisoned by strychnine like the native dogs' (Jevons 1876a, pp. 671-2). An editorial in the Spectator then suggested that the 'English public' reacted with 'absolute incredulity' to such statements and called on Jevons to substantiate his claims (Spectator 1876). In response, Jevons noted that his 'attention was first drawn to this matter by viva voce accounts received from a gentleman since dead'. He then referred to evidence from recent books on Queensland and to the Australian Sketcher for February 1876, concluding that 'a fierce war of extermination is now proceeding in North Queensland, uncontrolled 
by Government, and conducted with little regard to anything but the safety of the English invaders' (Jevons 1876b, p. 680). ${ }^{42}$ Jevons's conclusion stands in marked contrast with those today who like to think that the nineteenth-century Australian frontier was governed by 'the rule of law' and that talk of widespread violence is the product of a 'politically-motivated' conspiracy by late twentieth-century historians. ${ }^{43}$

\section{Appendix: W.S. Jevons's Australian Publications}

In the following list, Papers refers to Black and Könekamp (1972); Black (1973-81).

\section{6}

1. July 21. 'The Railway Discussion', Sydney Morning Herald, p. 3, signed 'Honestas'. Reprinted Papers, Letter 90.

2. September 3. Weekly meteorological reports begun in the Empire (p. 4), unsigned. Continued up to the end of June 1858. (Complete list in Inoue and White (2002, p. 351)).

\section{7}

3. February 10. 'The Western Line of Railway, and The General Policy of Government Railway Extension', Empire, p. 3, signed 'O'. Reprinted Papers, Letter 98.

4. February 26. 'Meteorology and the Herald', Empire, p. 3, signed ' $O$ '. Reprinted Papers, Letter 99.

5. March 27. 'The Solar Eclipse', Empire, p. 2, unsigned.

6. March 30. 'Protection', Empire, p. 3, signed 'O'. Reprinted Papers, Letter 102.

7. March 31. 'The Total Eclipse' (additional observations to weekly meteorological report), Empire, p. 4, unsigned.

8. April 8. 'Comparison of the Land and Railway Policy of New South Wales', Empire, p. 6, signed 'O'. Reprinted Papers, Letter 103.

9. April 27. 'Meteorology of Australia', Empire, p. 5, signed 'Met.Obs.'

10. May 4. 'On the Resolutions passed at the Protection Meeting', Empire, p. 5, signed ' $\mathrm{O}$ '.

11. June 24. 'The Public Lands of New South Wales', Empire, p. 4, signed 'From a Correspondent'. Reprinted Empire, 'Summary for England', July 17, 1857, pp. 3-4; Papers, 7, pp. 3-8.

12. June.

First monthly meteorological report for the Sydney Magazine of Science and Art, 1, no. 1, p. 20. Reports continued until end of June 1858, with two yearly summaries in July 1857 and July 1858. (Complete list in Inoue and White (2002, p. 352)).

13. July.

'On the Cirrous Form of Cloud', London, Edinburgh, and Dublin Philosophical Magazine and Journal of Science ( $4^{\text {th }}$ series), 14 , no. 90 , pp. 22-35. Published as a separate pamphlet, 1857.

14. July 14. 'On A Sun-gauge or New Actinometer', Empire, p. 3. Reprinted in Empire September 11, 1857, p. 2 (without diagrams); Sydney Magazine of Science and Art, 1, 
August 1858, pp. 58-62; London, Edinburgh, and Dublin Philosophical Magazine and Journal of Science $\left(4^{\text {th }}\right.$ series), 14, no. 94, November 1857, pp. 351-6.

15. August 6. 'Remarks' (additional observations on the barometer and meteorology in weekly meteorological report), Empire, p. 4, unsigned.

16. September 11. 'Meteorology of Australia', Empire, pp. 4-5, unsigned.

17. September 19. 'The Eclipse', Empire, p. 4, unsigned.

18. October 5. 'Lead Poison in the Sydney Water', Empire, p. 5, unsigned.

19. November 14. 'Gunpowder and Lightning', Empire, p. 3, signed 'Thunderbolt'.

20. December 29. 'Railway Economy', Empire, p. 4, signed 'An Exact Thinker'. Reprinted Papers, 7, pp. 8-11.

\section{8}

21. January.

'On Clouds; Their Various Forms, and Producing Causes', Sydney Magazine of Science and Art, 1, no. 8, pp. 163-76.

22. March 17. 'Remark' (additional observations on drought in weekly meteorological report), Empire, p. 4, unsigned.

23. April. 'On the Forms of Clouds', London, Edinburgh, and Dublin Philosophical Magazine and Journal of Science $\left(4^{\text {th }}\right.$ series), 15, no. 100, pp. 241-55.

24. April 14. 'A Cure for the Revenue', Empire, p. 4, signed 'A Correspondent'.

25. June.

'Rev. Mr Scott's Criticisms', Sydney Magazine of Science and Art, 2, no. 13, pp. 17-18. Reprinted Papers, Letter 118.

26. June 10. 'The Royal Prerogative of Mercy', Empire, p. 4, signed 'A Correspondent'.

27. August 3. 'New Facts Concerning the Interior of Australia', Empire, p. 5, unsigned.

28. September 27. Review article of the Sydney Magazine of Science and Art, 1, in Sydney Morning Herald, p. 8, signed 'J'.

29. October 7. 'The Social Cesspools of Sydney. No. I - The Rocks', Sydney Morning Herald, p. 2, signed 'A Correspondent'.

30. October 29. 'Canoona Diggings in a Scientific Aspect', Sydney Morning Herald, p. 3, signed 'W.S.J.' Reprinted Papers, Letter 124.

31. October. 'Remarks on the Geological Origin of Australia', Sydney Magazine of Science and Art, 2, pp. 89-93, unsigned.

32. October. 'Earthquakes in New South Wales', Sydney Magazine of Science and Art, 2, pp. 93-4, unsigned.

33.

'Social Survey of Australian Cities', Mss. No. B864, Mitchell Library, Sydney. Greater part published in instalments under the title, 'Sydney in 1858: A Social Survey', Sydney Morning Herald, Nov. 9, 13, 16, 23, 30 and Dec. 7, 1929.

\section{9}

34.

'Some Data concerning the Climate of Australia and New Zealand', Waugh's Australian Almanac for the Year 1859, (Waugh), Sydney, pp. 47-98. Published as a separate pamphlet 1859, 1863. 
35. January-Feb. 'Meteorological Observations in Australia, Being a Continuation of those Published in Waugh's Australian Almanac for 1859', Sydney Magazine of Science and Art, 2, pp. 161-7.

36. March.

'Meteorological Observations in Australia, Being a Continuation of those Published in Waugh's Australian Almanac for 1859', Sydney Magazine of Science and Art, 2, pp. 173-81.

37. May.

'On the Semidiurnal Oscillation of the Barometer', London, Edinburgh, and Dublin Philosophical Magazine and Journal of Science ( $4^{\text {th }}$ series), 17, no. 115, pp. 313-23.

38. May 3.

'A Notice of the Geology of the Australian Gold Fields', Proceedings of the Literary and Philosophical Society of Manchester; 1, no. 16, pp.134-6.

39. November 15. 'Remarks on the Australian Gold Fields', reported as 'Observations of the Gold Districts of Australia', Proceedings of the Literary and Philosophical Society of Manchester; 1, pp. 166-68. Printed in Memoirs of the Literary and Philosophical Society of Manchester; Series III, 1, pp. 115-30. Published as a separate pamphlet (Manchester), 1861.

\section{Notes}

1 While the usual caveat on responsibility for the final product applies, I am indebted to the staff (particularly Claudia De Salvo) at Document Delivery Services and the staff (particularly Richard Overall) at the Rare Books Collection, Matheson Library, Monash University; John Hodgson, Head of Archives, John Rylands University Library of Manchester, for a list of recent additions to the Jevons Archive; Bert Mosselmans for copies of the additions to the Jevons Archive; Rosalind White for research assistance; Ian Castles, Simon Guttmann, Jamie Kassler, Megan Martin and two anonymous referees for helpful comments and suggestions.

2 'The Late Professor Jevons', The Sydney Mail, 26 August 1882, p. 337. Inaugurated in May 1856, the Philosophical Society was an antecedent of the Royal Society of New South Wales (Maiden 1918; Day and Day 1984). Jevons was elected in June 1856. The etching in the Mail is rather odd. It appears to be taken from a mirror image of the photograph that was later published in the Letters \& Journal (Jevons 1886).

3 The exhibition (www.powerhousemuseum.com/exhibitions/jevons.asp) opened with a symposium held at the Museum in October 2004.

4 For the contemporary praise, see La Nauze (1949), pp. 29-30. For the subsequent commentary, see Schmitt (1995a and 1995b); Nicholls (1998); Maas (2005).

5 See Walker (1976, especially chapter 6) for the Empire.

6 Jevons Archive, John Rylands University Library of Manchester, JA 6/43/4.

7 The manuscript of the survey is in the Mitchell Library, Sydney, MS. B864. While the map accompanying the manuscript has been lost, Davison (1997-98, p. 141) has produced a partial reconstruction. See also La Nauze (1949, pp. 33-7, 43) and section 4 below.

8 JA $6 / 24 / 11-13$.

9 JA 6/24/1 - 6/24/10; 6/24/6. See Jevons (1905, pp. vii-viii, 106-7); White (2006).

10 See, however, Black (1973-81, 2, pp. 114, 208).

11 Jevons was helped by Clarke in his barometric readings and they discussed other meteorological matters (Black and Könekamp 1972, pp. 163n,167n; Black 1973-81, 2, p. 298; letter from Clarke to Jevons, 6 July 1857, JA 6/2/88). When Jevons offended Clarke by some remarks in the Sydney Morning Herald (item 30), Jevons hastened to 
heal the rift. Jevons also played a part in Clarke’s election to the Royal Society in 1876 (Moyal 2003, pp. 503-1, 539-40, 1147-8, 1168-9).

12 Groom and Wickman (1982, pp. 6-7); Snowden (1988). The Sydney Magazine of Science and Art recorded exhibitions of photographs at the Philosophical Society including some by Jevons (Dyer 1858-9, 1, pp. 253-4; 2, p. 131). A number of photos from Jevons's Australian album can now be viewed online, via the link at http://rylibweb.man.ac.uk/data2/spcoll/jevons/. A discussion of Smith's photography refers to an expedition to the Grose Valley in c.1858 by Smith and Hunt, noting that Jevons 'may have been on that or a similar expedition' (Snowden 1988, p. 26). A letter recently acquired by the Jevons Archive contains a long description of an expedition by Jevons and Hunt to the Grose Valley during Christmas 1858 but does not mention Smith (W.S. Jevons to H. Roscoe, 10 January 1859). A Hunt photograph from that expedition is reproduced in Barker (2005).

13 For Jevons's description of the Dunbar wreck, see Black (1973-81, 2, pp. 299302). Artefacts obtained by divers on the wreck were auctioned at Sydney in 1994 (Robson 1994; The Bulletin, 8 November 1994, p. 27). In attributing the photograph to Jevons, Iris Burke noted that it was annotated by Hunt. Burke also described the photograph as 'probably Australia's first camera news story' (Burke 1955, pp. 16-17). That odd characterisation was repeated by subsequent commentators (Moses 1959), one of whom, in describing the photo as 'the first Australian news photograph', also claimed that Jevons was 'a respected early colonial journalist with the Sydney Morning Herald' (!) (Flannery 2003, pp. 288, 341).

14 See, for example, Griffin (2003); Martin (2002, 2003a, 2003b); Martin and Griffin (2004).

15 For Severn, see Martin (2002); for his sun-gauge illustrations, Jevons's diary entry, 2 July 1857 (JA 6/4/2). (The illustrations in Jevons's published paper were attributed to a W. Hoddle.) For the glassblowing difficulty, Jevons to Henry Roscoe, 15 May 1857 (JA 16/1/80; Black 1973-81, 2, p. 344); for Bolton's letter to Jevons, JA 6/3/2. Bolton's letter possibly dealt with setting up an assay laboratory in Sydney (Black 1973-81, 2, p. 107).

16 La Nauze, who had been working on the Political Economy project since the early 1940s (La Nauze 1941; 1943), was then in the economics department at the University of Sydney. (His relationship with some of his colleagues was apparently rather fraught - see the odd acknowledgement in his book (La Nauze 1949, p. 6) and the review by another member of the department (Renwick 1950).) Only one of La Nauze's attributions of publications to Jevons now seems inaccurate. In the Sydney Magazine for May 1858, William Scott, the Colonial astronomer and meteorologist, referred to Jevons's article 'On Clouds' (item 21), observing that it contained 'no new theory' (Scott 1858, p. 264). An angry Jevons responded that he had been misrepresented and implied that Scott had been dishonest because the misrepresentation was based on a 'simple point....(that) could not have escaped' Scott (item 25). Scott had also criticised a review of G. Wight's Geology and Genesis (London, 1857) published by the Empire (12 March 1858, p. 2). Jevons appended a comment to his response suggesting that Scott supported a literalist reading of the first two chapters of Genesis. La Nauze (1949, p. 42) then inferred that Jevons had written the Empire review. (It was listed, with a question mark, in Inoue and White (2002).) The attribution now seems unsatisfactory. Scott identified the author as 'a clergyman of this colony' (Scott 1858, p. 265). Perhaps W.B. Clarke?

17 See also the biographical introduction by Rosamond Könekamp (1972) that discusses Jevons's Antipodean interlude.

18 Black, (1973-81, 7, pp. 123-4). The notebook is in the Jevons Archive (JA 6/4/12).

19 For the latest published version of the bibliography, see Inoue and White (2002). 
20 For references and discussion of the context in which Jevons used the work of Pell and Woolley, see White (1982 and 1989); Groenewegen (1990, pp. 18-23).

21 Referring to the appointment of Smith rather than Huxley, one commentator suggested that it was 'a substitution of steadiness for genius which has frequently characterised Australian university life’ (Moyal 1993, p. 163).

22 The following paragraph draws on Black and Könekamp (1972, p. 25); Black (1973-81, 2, pp. 75, 79, 151, 435, 442; 3, pp. 4-5). For detailed studies of Smith, see Macleod (1988).

23 Jevons's diary entry for 16 April 1857 recorded that, accompanied by Robert Hunt, he had been to see Smith at the University: 'Saw his barometer etc., and had some talk. Then to the New University at the Glebe, where we looked over the building and his new rooms, discussing the arrangements of the laboratory etc.' (JA 6/4/2).

24 See Coward (1988, pp. 8-18).

25 Smith also appeared as a witness before a parliamentary commission of enquiry into the Melbourne water supply, established in October 1858 (Dingle and Doyle 2003, p. 43).

26 The role of the Health Officer was severely compromised by the sectional interests of a number of city aldermen (Mayne 1982, chapter 4).

27 The paper was reprinted in the Empire (14/8/1856), Sydney Morning Herald (15/8/1856) and the Sydney Magazine of Science and Art (Volume I, No. 5, 1857, pp. 104-6).

28 Jevons's diary entries, 13-15 August 1856 (JA 6/4/2).

29 Black (1973-81, 2, pp. 249-50). Jevons referred to Witt (1856).

30 Aaron's report was published in the Empire, 29/9/1857.

31 The cavalier treatment of Jevons's time in Australia by some commentators is indicated by the following: 'if Jevons had wished to conduct research in theoretical or experimental chemistry, he had the time and the laboratory at hand to do so. Instead, he spent much of his spare time at the office reading the newspapers, and during the evenings he read books or played the organ' (Schabas 1990, p. 16).

32 Jevons purchased a copy of Quetelet's Treatise on Man (translation of 1842) in August 1857 and commented on it in a letter of January 1859 (Black 1973-81, 2, pp. 361-2; 7, p. 119). By November he had also read Herschel's Essays, which contained a long review article of Quetelet's work (Herschel 1857; Black 1973-81, 2, p. 308). For the context of this and significance for Jevons's division of labour project, see White (2006).

33 Jevons wrote in May 1857 that he did not 'like' the meetings of the Society as 'the old Governor [Sir William Denison] and Capt. Ward [Deputy Master at the Mint]....come out too strongly and patronisingly' (JA 16/1/8a), echoing a complaint he had made in the previous year (Black 1973-81, 2, p. 249). By September, however, after the success of his sun-gauge paper, Jevons reported that he was 'gradually becoming, perhaps I may say, quite a scientific authority in the place' (W.S. Jevons to Henry Roscoe, 8 September 1857. Letter recently acquired by the Jevons Archive). Denison and Ward were both Royal Engineers. In 1862 Jevons referred to 'those skilful place-hunters, the Royal Engineers' (Jevons 1862, p. 1020). That hostility might date from his Australian experience.

34 See Groom and Wickman (1982, pp. 48, 52). For the transformation of the Rocks as a tourism precinct today, see Morgan (1991).

35 Groom and Wickman also reprinted (pp. 80, 82) Jevons's 'Sydney by Night' manuscript, extracts from which had been discussed in La Nauze (1949).

36 Jevons began his 1858 Sydney Morning Herald article on the Rocks by noting that there 'are some subjects from which even the most scrupulous of readers during his morning glance over the paper, will avert his eyes'. Ninety years later, some Herald 
readers still preferred to avert their eyes from any discussion of Sydney slums (McQueen 1978, p. 181).

37 Illing (2005); Macintyre (2005).

38 Jevons left the colony in early 1859. It would, therefore, have been difficult for him to have spent 'years at the Sydney Observatory' which was only completed in 1858. Indeed, I know of no evidence that Jevons actually visited the Observatory where the government astronomer, William Scott, began taking observations in June 1858 (Pickett and Lomb 2001, pp. 22-4). The last of Jevons's signed monthly meteorological reports for the Sydney Magazine of Science and Art appeared in July of the same year. They were replaced from the next issue by unsigned reports from the 'Observatory Sydney', presumably written by Scott. The clash in June of that year between Jevons and Scott - see note 15 above - should be read in that context. I was also unaware that Jevons 'acquired some knowledge of the regular sunspot cycle' while in Sydney. Given the state of sunspot research at the time, it is truly astonishing that he did so. By the same token, the suggestion that Jevons's subsequent explanation of business cycles had something to do with the rings of tree-trunks is a novel, if not remarkable, addition to the existing literature. For it to stand as a stinging rebuttal to those academics, particularly 'in the social sciences, like economics', for whom 'scholarship is a rare thing', all that is now required is the trifling matter of producing the evidence that underpins it.

39 See the editorial in Quadrant, the journal for the academic manqué, any issue.

40 Australian Research Council (1998). The report was prepared by the Academy of the Social Sciences in Australia. See also Castles (1998).

41 In addition to the references cited above, see Perry (1966, pp. 145-8) (geography); Gentilli (1967, pp. 57-8) (meteorology). Max Kelly also used Jevons's social survey and photographs for his study of Paddington (Kelly 1978, pp. 9-10, 23-4).

42 The response is reprinted in Black (1973-81, 4, pp. 174-7).

See Attwood and Foster (2003); for Queensland in particular, Evans (2005).

\section{References}

Aaron, Isaac. 1858. 'Sanitary reform', Sydney Magazine of Science and Art 9, February, pp. 193-9.

Attwood, Bain and Foster, S.G. (eds). 2003. Frontier Conflict. The Australian Experience. Canberra: National Museum of Australia.

Australian Research Council. 1998. Challenges for the Social Sciences and Australia, Volume 1. Canberra: Australian Government Publishing Service.

Barker, Geoff. 2005. 'A passage from India', Sydney University Museums Newsletter 5, p. 7.

Barrett, Lindsay and Connell, Matthew. 2004. 'The curious economist', Powerline Spring, pp. 10-11.

Birmingham, John. 1999. Leviathan. The Unauthorised Biography of Sydney. Sydney: Random House.

Black, R.D. Collison and Könekamp, Rosamond (eds). 1972. Papers and Correspondence of William Stanley Jevons, Volume 1. Basingstoke: Macmillan.

Black, R.D. Collison (ed.). 1973-81. Papers and Correspondence of William Stanley Jevons, Volumes 2-7. Basingstoke: Macmillan.

Burke, Iris. 1955. 'Australia's first pictorialist', Australasian Photo Review 62, pp. 6-22. 
Castles, Ian. 1998. 'Vice President's note', Newsletter, Academy of the Social Sciences in Australia 17(3), pp. 5-12.

Clark, David. 1978. 'Worse than physic: Sydney's water supply 1788-1856', in Max Kelly (ed.), Nineteenth Century Sydney. Essays in Urban History. Sydney: Sydney University Press.

Coward, Dan. 1988. Out of Sight....Sydney’s Environmental History 1851-1981. Canberra: Australian National University.

Davison, Graeme. 1997-98. 'The unsociable sociologist: W.S. Jevons and his survey of Sydney, 1856-8', Australian Cultural History 16, pp. 127-50.

Day, A.A. and Day, J.A.F. 1984. 'A biographical register of members of the Australian Philosophical Society (1850-55) and the Philosophical Society of New South Wales (1856-66). Part I', Journal and Proceedings. Royal Society of New South Wales 117, pp. 119-27.

Dingle, Tony and Doyle, Helen. 2003. Yan Yean. A History of Melbourne's Early Water Supply. Melbourne: Public Record Office.

Dyer, J. (ed.). 1858-9. The Sydney Magazine of Science and Art: containing by authority, the Proceedings of the Australian Agricultural Society and the Philosophical Society of New South Wales, Volumes 1 and 2. Sydney: Waugh.

Evans, Raymond. 2005. 'Plenty shoot 'em. The destruction of Aboriginal societies along the Queensland frontier', in A. Dirk Moses (ed.), Genocide and Settler Society. Frontier Violence and Stolen Indigenous Children in Australian History. New York: Berghahn.

Flannery, Tim. 2003. The Birth of Sydney. Melbourne: Text.

Gentilli, J. 1967. 'A history of meteorological and climatological studies in Australia', University Studies in History 5(1), pp. 54-88.

Griffin, Robert. 2003. The Sydney Branch of the Royal Mint. Sydney: Historic Houses Trust.

Groenewegen, Peter. 1990. 'Neoclassical value and distribution theory: the English-speaking pioneers', in Klaus Hennings and Warren J. Samuels (eds), Neoclassical Economic Theory, 1870 to 1930. Boston: Kluwer.

Groom, B. and Wickman, W. (eds). 1982. Sydney - The 1850s. The Lost Collections, Macleay Museum, The University of Sydney.

Herschel, John F.W. 1857. Essays from the Edinburgh and Quarterly Reviews, with Addresses and other Pieces. London: Longman, Brown, Green, Longman \& Roberts.

Illing, Dorothy. 2005. 'Minister vetoes research projects', The Australian, 16 November.

Inoue, Takutoshi and White, Michael V. 1993. 'Bibliography of the published works of W.S. Jevons', Journal of the History of Economic Thought 15(1), pp. 122-47.

Inoue, Takutoshi and White, Michael V. 2001. 'Bibliography of the published works of W.S. Jevons', in The Writings on Economics of W.S. Jevons, Volume 1. Basingstoke: Palgrave, pp. xxvi-xliii.

Inoue, Takutoshi and White, Michael V. 2002. 'Bibliographical list of W. Stanley Jevons's writings, etc.', in Takutoshi Inoue (ed.), W. Stanley Jevons: Collected Reviews and Obituaries, Thoemmes Press, Volume 2, pp. 351411. 
Jevons, Harriet A. (ed.). 1886. Letters and Journal of William Stanley Jevons. London: Macmillan.

Jevons, W. Stanley. 1862. 'The clerk of the weather office', The Spectator, no. 1785, 13 September, pp. 1020-1.

Jevons, W. Stanley. 1876a. 'Cruelty to animals - a study in sociology', Fortnightly Review 19(113), p. 671-84. Reprinted in Jevons (1883).

Jevons, W. Stanley. 1876b. 'The alleged poisoning of natives in Queensland', The Spectator, May 27, pp. 679-80.0

Jevons, W. Stanley. 1883. Methods of Social Reform and Other Papers. London: Macmillan.

Jevons, W. Stanley. 1905. The Principles of Economics. A Fragment of a Treatise on the Industrial Mechanism of Society and Other Papers, edited by Henry Higgs. London: Macmillan.

Karskens, Grace. 2001. 'Small things, big pictures: new perspectives from the archaeology of Sydney's Rocks neighbourhood', in Alan Mayne and Tim Murray (eds.), The Archaeology of Urban Landscapes. Explorations in Slumland. Cambridge: Cambridge University Press.

Kassler, Jamie C. 1996. 'William Stanley Jevons and the mechanisation of logic', Australasian Music Research 1, pp. 327-35.

Kelly, Max. 1978. Paddock Full of Houses. Paddington 1840-1890. Paddington: Doak Press.

Könekamp, Rosamond. 1972. 'Biographical introduction', in Black and Könekamp (1972), pp. 1-52.

La Nauze, J.A. 1941. 'Jevons in Sydney', Economic Record 17, pp. 31-45. Reprinted in Wood (1988), volume I, pp. 109-24.

La Nauze, J.A. 1943. 'A Social Survey of Sydney in 1858', Historical Studies 2(8), pp. 274-8.

La Nauze, J.A. 1949. Political Economy in Australia, Historical Studies. Melbourne: Melbourne University Press.

La Nauze, J.A. 1954. 'Great British economist made a social survey of Sydney', Sydney Morning Herald, October 6, p. 3.

Maas, Harro. 2005. William Stanley Jevons and the Making of Modern Economics. New York: Cambridge University Press.

McGuinness, P.P. 1988. 'Gurus and trick cyclists', Australian Financial Review, 9 February.

McGuinness, P.P. 2003. ‘The anti-economists', Quadrant 47(7/8), pp. 117-8.

Macintyre, Stuart. 2005. 'Research floored by Full Nelson', The Age, 16 November.

Macleod, Roy (ed.). 1988. University and Community in Nineteenth Century Sydney. Professor John Smith 1821-1885. Sydney: University of Sydney.

McQueen, Humphrey. 1978. Social Sketches of Australia 1888-1975. Harmondsworth: Penguin.

Maiden, J.H. 1918. 'A contribution to a History of the Royal Society of New South Wales', Journal and Proceedings of the Royal Society of New South Wales 52, pp. 215-36.

Martin, Megan. 2002. 'Henry Severn. A Sydney Mint personality', Insites, Winter, p. 1.

Martin, Megan. 2003a. Colonial Science and the Sydney Mint. Sydney: Historic Houses Trust.

Martin, Megan. 2003b. 'Mr. Miller of the Mint', Insites, Winter, pp. 4-5. 
Martin, Megan and Griffin, Robert. 2004. 'Captain E.W. Ward, Royal Engineer: First Master at the Sydney Mint', Insites, Winter, pp. 2-3.

Mayne, A.J.C. 1982. Fever, Squalor and Vice. Sanitation and Social Policy in Victorian Sydney. St Lucia: University of Queensland Press.

Mosselmans, B. and Mathijs, E. 1999. 'Jevons's music manuscript and the political economy of music', in Neil De Marchi and Craufurd D.W. Goodwin (eds.), Economic Engagements with Art. Durham: Duke University Press.

Morgan, G. 1991. 'History on the Rocks', in J. Rickard and P. Spearritt (eds.), Packaging the Past? Public Histories, Melbourne: Melbourne University Press/Australian Historical Studies.

Moyal, Ann. 1993. A Bright \& Savage Land. Ringwood: Penguin.

Moyal, Ann. 2003. The Web of Science. The Scientific Correspondence of the Rev.W.B. Clarke, Australia's Pioneer Geologist, two volumes. Melbourne: Australian Scholarly Publishing.

Newton, Gael. 1988. Shades of Light. Canberra: Australian National Gallery /Collins.

Nicholls, Neville. 1998. 'William Stanley Jevons and the limate of Australia', Australian Meteorological Magazine 47(4), pp. 285-93.

Organ, Michael. 1992. 'W.B. Clarke as Scientific Journalist', Historical Records of Australian Science 9(1), pp. 1-16.

Perry, T.M. 1966. 'Climate and settlement in Australia 1700-1930', in John Andrews (ed.), Frontiers and Men. A Volume in Memory of Griffith Taylor (1880-1963). Melbourne: Cheshire.

Renwick, Cyril. 1950. Untitled review of La Nauze (1949), Economic Record 26, pp. 129-31.

Robson, Frank. 1994. 'Treasure hunters of the deep', Good Weekend, 15 January, pp. 16-21.

Rolleston, Christopher. 1857a. 'On the science of statistics', Sydney Magazine of Science and Art 12, May, pp. 254-8.

Rolleston, Christopher. 1857b. 'The sanitary condition of Sydney', Sydney Magazine of Science and Art 12, July, pp. 37-41.

Schabas, M. 1990. A World Ruled by Number. William Stanley Jevons and the Rise of Mathematical Economics. Princeton: Princeton University Press.

Schmitt, Raymond W. 1995a. 'The ocean's salt fingers', Scientific American, May, pp. 50-5.

Schmitt, Raymond W. 1995b. 'The salt-finger experiments of Jevons (1857) and Rayleigh (1880)', Journal of Physical Oceanography 25(1), pp. 8-17.

Scott, W. 1858. 'Correspondence', Sydney Magazine of Science and Art 12, May, pp. 264-5.

Sheldon, Peter. 1988. 'John Smith and the water question', in Macleod (1988).

Snowden, Catherine. 1988. 'The strayfaring Professor. John Smith and learned leisure', in Macleod (1988).

Spectator, 1876. 'Professor Stanley Jevons on vivisection', The Spectator, 29 April, pp. 554-5.

Walker, R.B. 1976. The Newspaper Press in New South Wales, 1803-1920. Sydney: Sydney University Press.

Walsh, Vivian and Gram, Harvey. 1980. Classical and Neoclassical Theories of General Equilibrium. New York: Oxford University Press. 
White, Michael V. 1982. 'Jevons in Australia: a reassessment', Economic Record 58(160), pp. 32-45.

White, Michael V. 1989. 'Jevons's Antipodean Interlude: rejoinder', History of Political Economy 21(4), pp. 623-31.

White, Michael V. 2004. 'A grin without a cat: W.S. Jevons's elusive equilibrium', in Tony Aspromourgos and John Lodewijks (eds), History and Political Economy. Essays in Honour of P.D. Groenewegen. London: Routledge.

White, Michael V. 2006. 'A painful disposition to classification: W.S. Jevons's first statistical chart in political economy', typescript.

Witt, H.M. 1856. 'On the variations in the chemical composition of the Thames water, during the year between May 1855 and May 1856', London, Edinburgh, and Dublin Philosophical Magazine and Journal of Science (4th series), 12(77), pp. 114-24. 